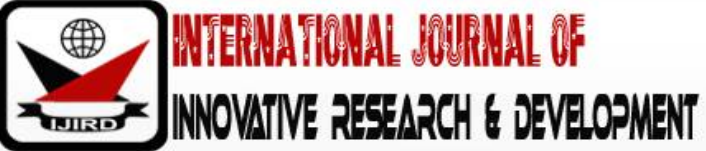

ISSN 2278 - 0211 (Online)

\section{The Impact of Population Growth on Urban Expansion: An Assessment of Obudu Town in Cross River North Senatorial District, Nigeria}

Isomkwo, Abonmaye Eddy
Chief Lecturer, Department of Economics,
Federal College of Education, Obudu, Nigeria
Dzum, Tyohemba Joseph
Senior Lecturer, Department of General Studies (GSE),
Federal College of Education, Obudu, Nigeria

\begin{abstract}
:
The study examined the impact of population growth on urban expansion in Obudu town. To guide the objectives of the study, four hypotheses were formulated for the study. Literature is reviewed based on the variables and hypotheses of the study. Survey research design was adopted, and 400 respondents using the Yaroyamene method was used to calculate the sample. Simple random sampling techniques was adopted. The method used in data collection was the questionnaire, designed by the researchers and validated by an expert of test and measurement. Chi-square (X2) and Pearson product moment correlation was used in testing the hypotheses. Base on the findings, some recommendations were made to the government, residents of Obudu town and future researchers on the subject under study.
\end{abstract}

Keywords: Impact, population growth \& urban expansion

\section{Background to the Study}

\subsection{Introduction}

Population is not just about numbers, it is about people. Living things especially humans reproduce, grow, and eventually die. While alive they may be compressed by some circumstances to migrate to other locations. As these events occur in an area, it brings about changes in the total size, composition and distribution in space of its population. The population of an area may increase, decrease or remain static depending on the number of births and net migration that occur in a place. Population growth refers to the numerical change in the size of a region's population between two periods (e.g. between 2004 and $2005 \mathrm{AD}$ ). The rate of growth is usually expressed in percentage per year (Anyanwuocha, 2004).

According to Umoh (2012), the growth of the population (positive and negative) in an area over a certain period planned is basically the sum of the natural replacement which has taken place plus the net migration into the area during the period in question. An area which suffers a higher rate of emigration in relation to natural replacement may experience a decline in its population. If on the other hand, the region enjoys a higher natural replacement in relation to emigration (low) it will experience population growth. Different places may have different total populations, number of births and net migration; as such places are bound to experience differences in their growth. The growth of population in an area reflects the history of the people response's to the environmental possibilities within the area. Evidence provided by past behaviour of population growth is equally the bedrock for estimating future trend in population growth.

Population growth is of considerable importance as guide to future physical, economic and socio-political planning. This is not withstanding as a measure of change, it is more useful to talk of the population growth rate of a country between two time periods than for much smaller administrative units. This is because national boundaries are more stable than those of smaller administrative divisions (e.g. Autonomous communities, clans, villages, local government area) like Obudu in Cross River State of Nigeria.

Merricle (2007), observed that the population growth in Nigeria in general and Obudu in particular result from an interplay of many factors such as increases in the birth rate, a decrease in the death rate or by higher net migration.

The population growth affects the urban area since the country moved from a predominantly rural background with some products of urban area as described by Hull (2001), as over grown rural villages to a nation with not less than six million cities (Goliber, 2000). Besides the larger cities, there are scores of other urban centres across the country. The phenomenal shifts of a hitherto predominantly rural population to a predominantly urban area irrespective of the perceived advantage is highly portentous. Sule (2004). Observed that an urban areas is a compact settlement with not less 
than 5,000 inhabitants and not more than 20,000, but inhabitants like Obudu town, the effect or impact which population has on urban expansion include congestion, resulting to environmental pollution increase in social problems, pressure on social services, increase in general expenditure, balance of payment problems, consequent fall in the standard of living etc. It is in the light of these that the researchers intend to investigate and come out with lasting solution to the impact of population growth on urban expansion in Obudu Town.

\subsection{Statement of the Problem}

The role population plays in a country cannot be overemphasized. The attributes of population such as age structure, sex distribution, marital status, religion, household size and composition, occupational structure and place of residence can change. These changes may influence positively lives ofindividuals and the society at large. Based on these, the government of each country spends a lot on this and help create awareness on people of the necessity of population growth to a country. Despite this importance of population growth to a country, there are some problems which it has created which needed to be addressed. Such problems include:

- Increase in dependency ratio.

- Increase in social vices.

- Increase pressure on land which results in fragmentation and over utilization including infrastructure.

- Size of urban force increase.

- Bottlenecks in social services

- High rate of unemployment.

In the light of these, the researchers intend to find a lasting solution to the impact of population growth on urban expansion in Obudu town.

\subsection{Aims and Objectives/ Purpose}

The aim of this work is to examine the impact of population growth on urban expansion in Obudu town. The objectives of the study are as follows:

- To examine the causes of population expansion in Obudu town.

- To ascertain the extent of how population affects housing in Obudu town.

- To determine the effects of environmental pollution caused by population growth in Obudu town.

- To proffer solution on the impact of population growth on urban expansion in Obudu town, particularly on increasing social vices and pressure on infrastructure.

\subsection{Research Questions}

The following research questions have been posed to guide the study.

- Does population growth affect housing services negatively in Obudu town?

- Does population growth lead to increase in social vices in Obudu town?

- To what extent has population growth affected agricultural land in Obudu town?

- How does population growth cause environment pollution in Obudu town?

\subsection{Research Hypotheses}

The following hypotheses were postulated for the study

- There is no significant relationship between population growth and housing pressure in Obudu town.

- There is no significant relationship between population growth and pressure on social services in Obudu town.

- There is no significant relationship between population growth and pressure on agricultural land in Obudu town.

- There is no significant relationship between population growth and environmental pollution in Obudu town.

\subsection{Significance of the Study}

The importance of the study cannot be overemphasized. It is hoped that the result of this study could be potentially useful to government, researchers, students and the public.

It will help the government in formulating unique policies and promote appropriate knowledge on how population growth affects urban expansion. It is hoped that both the federal and state ministries of education and the department of urban and regional planning will make use of the findings in policy making. It is believed that, the findings of this study will serve as a valuable and useful guide to future researchers in the field of Urban and Regional planning and other related disciplines. It is our conviction that this study will help researchers justify some of the factors that characterized the effects or impact of population growth on urban expansion and effectively help in providing positive result. This study will also be of immense importance to the area under study (Obudu urban).

This study will also assist urban potential planners to be able to plan ahead in other to avoid problems which they are expected to encounter. Parents will also become aware of how population growth affects urban expansion.

\subsection{Scope of the Study}

This study seeks to cover the impact of population growth on urban expansion in Obudu Local Government Area of Cross River State. Other areas to be covered include: 
- Population and increased on social vices in Obudu town.

- Housing and urban expansion in Obudu town.

- Population and environmental pollution in Obudu town.

- Causes of population expansion in Obudu town.

\subsection{Study Area}

Obudu local government area is located on a high plain within the guinea savannah and was created in 1976. It has a population of 161,457 in 2006 National Population Census Report. Obudu local government area on the world map lies between longitude $11.14^{\circ}$ and12.35 ${ }^{\circ}$ East of Greenwich Meridian and between latitude $0^{\circ}$ and $20^{\circ}$ North of the equator. It is one of the eighteen (18) local government areas of Cross River State and one of the five (5) local government areas that make up the Northern senatorial district of Cross River State. By the Northern hemisphere, Obudu is bounded by Kwande and Vandiekya local government areas of Benue State and Bekwarra local government area of Cross River State, at the East by Obanliku local government area,West by Mbube communities of Ogoja local government area and Boki local government area by the South. Obudu is inhabited predominantly by Bette speaking. It is majorly composed of the Obudu proper and the Utugwang who are mostly subsistence farmers. Cash crops such as groundnuts, ginger and soya beans are produced by them. Also produced are yams and cassava in commercial quantity.

The area has potentials for livestock farmingand solid minerals exploration. The areas include: Quartz and Gold both found in Okorontong hills in large quantities and not tapped significantly. Major tourist attraction is the popular Obudu new yam festival celebrated on the first week of September, (Icemo, 2007).

\subsection{Definition of Terms}

Population: This refers to the universe of human beings with distract or distinct individual and group characteristics such as the total number, composition, distribution in space and changes in these attributes.

Urban expansion: Increase in size of the number of both human and housing.

- Housing: Apartment that people live in.

- Pollution: The process of making air, water and soil unsafe.

\subsection{Theoretical Framework}

The most appropriate theories best suited for this work are Malthus theory on population and the Humer Hoty sector theory.

Thomas Robert Malthus a British economist and demographer who in one of his famous works "an essay on the principles of population", stated that while the population of the world increase in geometric proportions, the food resources available for them would increase only in arithmetic proportions. This theory is in conformity with the existing situation in the study area, because areas that were originally designed for farming have been overthrown to other land uses, especially residential, education and commercial area. Also, the habit of white cola jobs mentality has been injected into the blood stream of the inhabitants thereby reducing the activities of farming, leading to a reduction in food production on a daily basis.

Some critics of Malthus, like Karl Marx argued that Malthus failed to recognize the potential of human population to increase food supply.

He was also accused by his critics of having failed to comprehend man's ability to use science and technology to increase food supply to meet the needs of an increasing population.

Subsequently, Obudu entity has grown with a new technology of increasing the number of roads construction to link rural areas for supply of food the urban centre.

This theory is relevant in this study because, it goes to show that human population will continue to increase as long as man lives. The increase in population will consequently result in the high demand for housing (accommodation) and this will eventually culminate in the expansion of the town through increase in housing supply.

The sector theory of an urban internal spatial structure was formulated by Homer Hoyt in 1939. The sector model was focused on residential development planning. This theory states that residential land uses tend to be arranged in a wedgelike manner or sector radiating from the centre of the city along the lines of transportation.

Hoyt model is in conformity with the study area, since there is a commercial area in the centre of the urban. Ranch road and Ogoja road areas are major routes of transportation. Settlement are highly concentrated within this axis than any other area of the town.

Also, an argument put forward by Holt was on rent. According to him, rent area in American cities tend to conform to a pattern of sectors rather than on concentric circle. The highest rent areas of the city. There is a graduation of rentals downwards from these areas in all directions. Intermediate rental areas are those ranking next to the highest rental areas, adjoined the high rent areas on one or more sides, while low rent areas occupy other areas of the city form the central business district (C.B.D) to the periphery.

Hitherto, the above view of Hoyt has a semblance of Obudu urban because the high rent areas are Hospital road, Ogoja road, Ranch road and Bekpam layout. Next are the intermediate areas of Undigie and Abonkib sectors, likewise the lowest rent areas are: Okwel-Obudu axis, Atiekpe and the interior part of Bebuabong which occupies the peripheral sectors of the town. It is important to point out here that these rend areas are in conformity to Hoyt designation of not been static but dynamic. In other words, a low- or high-quality residential area in a certain sector could be migrating outward into another sector. Hoyt identified ten rent areas which are in conformity with the study as follows: 
- High-grade residential growth tends to proceed from the given point of origin along established lines of travels or toward another existing nucleus of buildings or trading centres.

- The zone of high rent areas tend to progress towards high ground which is free from risk of floods and to spread along lake, by river and ocean fronts, where such water points are not used for industry.

- High-rent residential districts tend to grow towards the sector of the city, which is a free, open country beyond the edges and away from "dead end" sections, which are limited by natural or artificial barriers to expansion.

- The higher priced residential neighbourhood tends to grow towards the homes of the leader of the community.

- Trends of movement of office buildings, banks and stores pull the higher prices residential neighbourhoods in the same direction.

- High-grade residential areas tent to develop along the fastest existing transportation line.

- The growth of high-rent neighbourhoods continues in the same direction for a long period of time.

- De-Luxe high rent apartment areas tend to be established near the business centres to hold in old residential areas.

- Real estate promotes may bend the direction of high-grade residential growth.

- The high rent neighbourhoods of a city do not skip about at random in the process of movement, they follow a definite part in one or more sectors of the city.

It is apparent that the outward immigration of high class residential area salong established lines of travel is likely to be persistent and is particularly pronounced along lines of fastest transportation, along water front's not used for industry and towards high ground, open country, the homes of community leaders and existing nuclei of building or trading centres. The Hoyt's model provides a model for planning towns and cities. Even when it is patterned after the western cities, the model is applicable to the planning of cities in non-western countries of the world. For example, in Calabar - Nigeria. The sector model seems to have been very useful in the understanding of the internal spatial structure of the city of Calabar and Obudu in particular.

\section{Research Methodology}

A research work of this nature requires not only an interest in the topic but very importantly the availability of data that is reliable and valid. This area is therefore, concerned with the design adopted by the researchers, the population and the sampling technique used, the description of the instrument and procedure employed to collect data for testing the hypotheses for the study.

\subsection{Research Design}

The design used for this study is the survey design. survey design is concerned with finding, describing and interpreting the relationship that exist, practices that prevail, attitudes that are held and processes that are developing. It is an attempt to collect data from members of a population in order to determine the correct status of the population with regards to one or more variables.

The survey design was adopted because the study involves drawing of inferences for generalization (Gay, 2003). The study depends basically on interview and questionnaire.

\subsection{Population}

The population of the study consist of the adult males and females. Random sampling method was adopted, and areas covered in Obudu town will include: Bishiri road, Market road, Ogoja road, Calabar road, Hospital road, Anderson street, Atekpe and Bekpam layout.

The adults from each unit were administered questionnaires making a total of 400 questionnaire covering Obudu town.

\subsection{Instrumentation}

The main instrument for data collection was the questionnaire, designed by the researchers. The questionnaire was divided into two sections. Section A and B.Section A was designed to collect the respondent demographic data such as sex, age, educational qualification, social status etc. while section Bis a four-point Likert type scale designed to assess the impact of population growth on urban expansion.

\subsection{Sources of Data}

The sources of data for this study consists both the primary and secondary sources. The primary sources are the questionnaire, interview and observation while the secondary sources come from textbooks, gazettes, newspapers and magazines.

2.5. Sample

The sample population used for the study is 400 respondents to arrive at the sampled population. The Yaroyamene formula for calculating finite population was given as: 
Yaroyamene formula

$$
\begin{gathered}
n=\frac{N}{1+N(e)^{2}} \\
\text { Where } \mathrm{n}=\text { sample size } \\
\mathrm{N}=\text { finite populace } \\
\mathrm{e}=\text { level of significance } \\
n=\frac{161,457}{1+161,457(0.05)^{2}} \\
n=\frac{161,457}{1+161,457(0.0025)} \\
n=\frac{161,347}{404.6425} \\
n=399.01 \\
n \cong 400
\end{gathered}
$$

\subsection{Sampling Techniques}

The sampling technique adopted for this study is the simple random sampling, Isangedighi (2004) asserted that a sample random sampling technique is a means by which researchers give every member of the population equal and independent opportunity of being selected. Random sampling technique entails composing a sample that will provide responses to each data that can be generalized to a large population.

The technique employed by the researchers is the hat and drame (balloting) method. Here the researchers wrote the names of all the entities in Obudu town selected in a slip of paper. Roll each slip into a paper ball, put in a container and blindly draw the required members of the community in the same manner the required samples used is randomly drawn for the study.

\subsection{Method of Data Processing}

The instrument was administered in person by the researchers to the respondents. This was to create uniformity. The researchers explained to them the purpose of the questionnaire and also demanded their cooperation and were assured that any information released during the course of the study by the respondents will be treated in strict confidence and used mainly for the purpose of this study.

\subsection{Statistical Method}

The statistical method for this study is the chi-square $\left(\mathrm{x}^{2}\right)$ analysis and the Pearson product moment correlation, chi-square $\left(\mathrm{x}^{2}\right)$ analysis is a non parametric statistic used in research which deals with testing of one or two variables. Here all the hypotheses are tested at 0.05 level of significance chi-square $\left(\mathrm{x}^{2}\right)$ is tested using frequencies and tables. The formula for chi-square is $\left(\mathrm{x}^{2}\right)$.

$$
\left(\mathrm{x}^{2}\right)=\frac{\sum(\mathrm{fo}-\mathrm{fe})^{2}}{\mathrm{fe}}
$$

Where: $f e=$ frequency Expected

$$
\begin{aligned}
& \text { fo }=\text { frequency observed } \\
& \left(\mathrm{x}^{2}\right)=\text { chi-square } \\
& \Sigma=\text { sum of }
\end{aligned}
$$

While Pearson product moment correlation analysis deals with the relationship that exist between variables: The formula for the Pearson product moment correlation is;

$$
\frac{\mathrm{r}=\Sigma(\mathrm{x}-\mathrm{x})(\mathrm{y}-\mathrm{y})}{\left.\left(\mathrm{x}-\mathrm{x}^{2}\right) \sum(-)-\mathrm{y}\right)^{2}}
$$

\section{Data Presentation, Analysis, Interpretation and Discussion of Findings}

\subsection{Introduction}

The research hypotheses were tested using chi-square $\left(\mathrm{x}^{2}\right)$ statistical tool.

\subsubsection{Test of Hypotheses}

Hypotheses formulated in the course of this study were tested using the chi-square $\left(\mathrm{x}^{2}\right)$ and Pearson product moment correlation coefficient statistical tool and value at 0.05 level of confidence. 


\subsubsection{Hypothesis One}

- Ho: There is no significant relationship between population growth and housingpressure in Obudu town.

- H1: There is significant relationship between population growth and housing pressure in Obudu town.

Pearson product moment correlation analysis was used in testing the data. The result is presented in table 4.1 correlation between population growth and housing in Obudu town.

\begin{tabular}{|c|c|c|c|c|c|c|c|}
\hline $\begin{array}{c}\text { Years } \\
2006\end{array}$ & $\begin{array}{c}\text { X No of } \\
\text { New } \\
\text { Migrant }\end{array}$ & $\begin{array}{c}\text { Y of no Newly } \\
\text { Constructed } \\
\text { Houses }\end{array}$ & $\mathbf{x}-\mathbf{x}$ & $\mathbf{y}-\mathbf{y}$ & $\mathbf{( x - x ) 2}$ & $\mathbf{( y - y ) 2}$ & $\mathbf{x}-\mathbf{x}(\mathbf{y}-\mathbf{y})$ \\
\hline 2007 & 10 & 10 & -16 & -4 & 256 & 16 & -64 \\
\hline 2008 & 20 & 15 & -6 & -1 & 36 & 1 & -6 \\
\hline 2009 & 10 & 10 & -16 & -4 & 256 & 16 & 64 \\
\hline 2010 & 40 & 15 & 14 & 1 & 196 & 1 & 14 \\
\hline 2011 & 50 & 20 & 24 & 6 & 576 & 36 & 144 \\
\hline & $\begin{array}{c}\Sigma x=130 \\
\mathrm{X}=130\end{array}$ & $\begin{array}{c}\Sigma \mathrm{y}=70 \\
\mathrm{y}=14\end{array}$ & 0 & 0 & $\Sigma(\mathrm{x}-\mathrm{x})^{2}=1320$ & $\Sigma(\mathrm{y}-\mathrm{y})^{2}=70$ & $\Sigma(\mathrm{x}-\mathrm{x})(\mathrm{y}-\mathrm{y})=152$ \\
\hline
\end{tabular}

Table 1: Correlation between Population Growth and Housing Supply in Obudu Town

$$
\mathrm{N}=400
$$

Standard deviation of $\mathrm{x}$ and $\mathrm{y}$

$$
\begin{gathered}
=\frac{130}{5}=26 \\
y=\frac{70}{5}=14 \\
r=\frac{\sum(x-\bar{x})(y-\bar{y})}{\sqrt{\sum\left(x-x^{2}\right)(y-y)^{2}}} \\
r=\frac{152}{\sqrt{1320 \times 70}} \\
r=\frac{152}{\sqrt{92400}} \\
r=\frac{152}{303.97} \\
r=\frac{0.50}{\sqrt{1-r^{2}}} \\
\text { when } r=0.50 \\
t=\frac{0.50(5-1)}{\sqrt{1-(0.50)^{2}}} \\
t=\frac{0.50(4)}{\sqrt{1-(0.50)^{2}}} \\
t=\frac{2}{\sqrt{1-0.25}} \\
t=\frac{2}{\sqrt{0.75}} \\
t=\frac{2}{0.866} \\
t=2.31 \\
t=1
\end{gathered}
$$

Since the calculated value of 0.35 was less than critical value of 2.27 at 0.05 level of confidence and four (4) degrees of freedom. The null hypothesis was thus accepted and alternative hypothesis rejected. This means there is significant relationship between population growth and housing in Obudu town.

\subsubsection{Hypothesis Two}

- Ho: There is no significant relationship between population growth and pressure on social services in Obudu town. 
- Hi: There is significant relationship between population growth and pressure on social services in Obudu town.

\begin{tabular}{|c|c|c|c|c|}
\hline Variable & Yes & No & \multicolumn{2}{|c|}{ Percentage } \\
\hline Population effect & 152 & 62 & \multicolumn{2}{|c|}{214} \\
\hline Social vices & 60 & 126 & \multicolumn{2}{|c|}{186} \\
\hline Total & 212 & 188 & \multicolumn{2}{|c|}{400} \\
\hline O & E & $0-\mathrm{E}$ & $(\mathrm{O}-\mathrm{E})^{2}$ & $\mathrm{O}^{-E^{2}}$ \\
\hline 152 & 113.42 & -38.58 & 14488.4164 & 13.12 \\
\hline 62 & 100.58 & -38.58 & 14488.4164 & 14.80 \\
\hline 60 & 98.58 & -38.58 & 14488.4164 & 15.10 \\
\hline 126 & 87.42 & -38.58 & 14488.4164 & 17.03 \\
\hline Total & & & & 60.05 \\
\hline
\end{tabular}

Table 2: Chi-Square $\left(\mathrm{X}^{2}\right)$ Analysis of Effect of Population Growth Pressure in Social Services PL 05, Df $(C-1)(R-1)=1$, Crit $X^{2}=3.84$

The result of the analysis revealed that the calculated chi-square (x2) value of 60-05 was higher than the critical value of 3.84 at 0.05 level of significance and on (1) degree of freedom. The null hypothesis was thus rejected and accept the alternative hypothesis. This means that there is significant effect of population growth and pressure on social services in Obudu town.

\subsubsection{Hypothesis Three}

- Ho: There is no significant relationship between population growth and loss of agricultural land in Obudu Urban.

- Hi: There is significant relationship between population growth and loss of agricultural land in Obudu town.

To test this hypothesis, Pearson product moment correlation analysis was used.

\begin{tabular}{|c|c|c|c|c|c|c|c|}
\hline $\begin{array}{l}\text { Years } \\
2006\end{array}$ & $\begin{array}{c}\text { X No of new } \\
\text { migrant }\end{array}$ & $\begin{array}{c}\text { Y of no newly } \\
\text { constructed } \\
\text { houses }\end{array}$ & $\mathbf{x}-\mathbf{x}$ & $y-\mathbf{y}$ & $(x-x) 2$ & $(y-y) 2$ & $x-x(y-y)$ \\
\hline 2007 & 30 & 5 & -26 & -4 & 676 & 16 & 104 \\
\hline 2008 & 50 & 7 & -6 & -2 & 36 & 4 & 12 \\
\hline 2009 & 100 & 10 & 44 & 1 & 1936 & 1 & 44 \\
\hline 2010 & 60 & 8 & 4 & -1 & 16 & 1 & 4 \\
\hline 2011 & 40 & 15 & -16 & 6 & 256 & 36 & 96 \\
\hline & $\begin{array}{l}\sum x=56 \\
X=280\end{array}$ & 45 & & & $\Sigma(\mathrm{x}-\mathrm{x})^{2}=2920$ & $\Sigma(\mathrm{y}-\mathrm{y})^{2}=58$ & $\Sigma(\mathrm{x}-\mathrm{x})(\mathrm{y}-\mathrm{y})=260$ \\
\hline
\end{tabular}

Table 3: Correlation between Population Increase and Loss of

$$
\text { Agricultural Land in the Urban Periphery }
$$

$$
\mathrm{N}=400
$$

Standard deviation of $\mathrm{x}$ and $\mathrm{y}$

$$
\begin{gathered}
\frac{280}{5}=56 \\
y=\frac{45}{5}=9 \\
r=\frac{\sum(x-\bar{x})(y-\bar{y})}{\sqrt{\sum\left(x-x^{2}\right)(y-y)^{2}}} \\
r=\frac{260}{\sqrt{\sum(2920) \times 58}} \\
r=\frac{260}{\sqrt{169360}} \\
r=\frac{260}{411.53} \\
r=0.64 \\
t=\frac{r(n-1)}{\sqrt{1-r^{2}}}
\end{gathered}
$$




$$
\begin{array}{r}
t=\frac{0.64(5-1)}{\sqrt{1-(0.64)^{2}}} \\
t=\frac{0.64(4)}{\sqrt{1-(0.64)^{2}}} \\
t=\frac{2.56}{\sqrt{1-0.4096}} \\
t=\frac{2.56}{\sqrt{0.5904}} \\
t=\frac{2.56}{0.7684} \\
t=3.33
\end{array}
$$

$$
t_{c}=2.13 \quad \varangle_{t}=3.33
$$

The table above shows that the critical value of 2.13 at 0.05 level of confidence and degree of freedom is less than the calculated value of 2.16 since the calculated is greater than the critical value, and then the research hypothesis is rejected and accepts the alternative hypothesis. This means that there is a significant relationship between population increases and loss of agricultural land on the urban periphery.

\subsubsection{Hypothesis Four}

- Ho: There is no significant relationship between population growth and environmental pollution in Obudu town.

- H1: There is significant relationship between population growth and environmental pollution in Obudu town.

To test this hypothesis Pearson product moment correlation analysis was used.

\begin{tabular}{|l|l|l|l|l|l|l|l|}
\hline $\begin{array}{c}\text { Years } \\
\mathbf{2 0 0 6}\end{array}$ & $\begin{array}{l}\text { X No of new } \\
\text { migrant }\end{array}$ & $\begin{array}{c}\text { Y of no newly } \\
\text { constructed } \\
\text { houses }\end{array}$ & $\mathbf{x}-\mathbf{x}$ & $\mathbf{y}-\mathbf{y}$ & $\mathbf{( x - x ) 2}$ & $\mathbf{( y - y ) 2}$ & $\mathbf{x}-\mathbf{x}(\mathbf{y}-\mathbf{y})$ \\
\hline 2007 & 30 & 5 & -26 & -4 & 676 & 16 & 104 \\
\hline 2008 & 50 & 7 & -6 & -2 & 36 & 4 & 12 \\
\hline 2009 & 100 & 10 & 44 & 1 & 1936 & 1 & 44 \\
\hline 2010 & 60 & 8 & 4 & -1 & 16 & 1 & 4 \\
\hline 2011 & 40 & 15 & -16 & 6 & 256 & 36 & 96 \\
\hline & $\begin{array}{l}\Sigma \mathrm{x}=56 \\
\mathrm{X}=280\end{array}$ & 45 & & & $\Sigma(\mathrm{x}-\mathrm{x})^{2}=2920$ & $\Sigma(\mathrm{y}-\mathrm{y})^{2}=58$ & $\Sigma(\mathrm{x}-\mathrm{x})(\mathrm{y}-\mathrm{y})=260$ \\
\hline
\end{tabular}

Table 4: Correlation between Population Growth and Environmental Pollution in Obudu Town

$$
\mathrm{N}=400
$$

Standard deviation of $\mathrm{x}$ and $\mathrm{y}$

$$
\begin{gathered}
=\frac{280}{5}=56 \\
y=\frac{45}{5}=9 \\
r=\frac{\sum(x-\bar{x})(y-\bar{y})}{\sqrt{\sum\left(x-x^{2}\right)(y-y)^{2}}} \\
r=\frac{260}{\sqrt{\sum(2920) \times 58}} \\
r=\frac{260}{\sqrt{169360}} \\
r=\frac{260}{411.53} \\
r=0.64 \\
t=\frac{r(n-1)}{\sqrt{1-r^{2}}} \\
t=\frac{0.64(5-1)}{\sqrt{1-(0.64)^{2}}}
\end{gathered}
$$




$$
\begin{aligned}
t & =\frac{0.64(4)}{\sqrt{1-(0.64)^{2}}} \\
t & =\frac{2.56}{\sqrt{1-0.4096}} \\
t & =\frac{2.56}{\sqrt{0.5904}} \\
& t=\frac{2.56}{0.7684} \\
t_{c}=2.13 \quad t_{\mathrm{t}}=3.33 \quad & t=3.33
\end{aligned}
$$

The table above shows that the critical value of $2 / 13$ at 0.05 level of confidence and degree of freedom is less than the calculated value of 2.16 since the calculated is greater than the critical value and then the research hypothesis is rejected and accepts the alternate hypothesis. This means that there is a significant relationship between population growth and environmental pollution in Obudu town.

\subsection{Discussion of Findings}

\subsubsection{Population Growth and Housing} Obudu town.

Hypothesis one revealed that there is significant relationship between population growth and housing pressure in

The findings are in line with Adeleke and Leong (1981). They observed that housing problems is often acute, especially in fast growing towns and cities. Many families are crumbled into small houses partly ventilated and unhealthy. Many are permanent pavement dwellers and some spend their whole lives in slums. This group of people are almost inevitable in every major city.

One of the most vexing problems of rapid urbanization in many developing countries of the world is that of illegal occupation of lands for the purpose of housing. Also Sule (2006) said that one of the most vexing problems of rapid urbanization and spatial polarization of socio-activities in African is the shortage of housing this was the situation as observed by the researchers about Obudu town.

\subsubsection{Population Growth and Pressure on Social Services}

The result of the data analysed in respect of hypothesis two revealed that there is significant effect of population growth on social services in Obudu. In support of this result, Anyawuocha (2004) opined that the existing facilities will not be sufficient. There will be heavy pressure on housing, water supply, educational facilities, health facilities etc resulting in their uses and consequent breakdown. Also, Ndukwe (2005) observed that population explosion in the urban areas leads to congestion, overcrowding along the street, market, public squares etc. This in turn lead to the shortage of some essential amenities such as water, electricity, fire woods, kerosene, residential housing, educational facilities, including classroom spaces, health services and hospital facilities.

\subsubsection{Population Growth and Loss of Agricultural Land at the Urban Periphery}

Hypothesis three, this hypothesis revealed that there is a significant relationship between population increase and loss of agricultural land at the urban periphery in Obudu town.

This finding is in line with Mobogunge (1999) who said that as the city grows population size increases so do the complexity of its land uses become more manifest. This explains why the sitting of an airport in part of Obudu town generate violence against government officials who were sent to survey and level a piece of land earmarked as suitable for airport. The claim of the locals was that their farmland was being taken over without replacement.

\subsubsection{Population Growth and Environment Pollution in Obudu Town}

This hypothesis revealed that there is a significant relationship between population growth and environmental pollution in Obudu town. Thus, as the land uses becomes more complex so does the solid waste generated increase in volume and variety. This is true of Obudu town where refuse dumps can be seen opposite Sacred Heart Hospital Obudu polluting the environment if vehicles for refuse removal breakdown for a day or two.

\section{Summary, Conclusion and Recommendations}

\subsection{Summary of the Study}

The main aim of the study was to investigate the impact of population growth on urban expansions in Obudu town. To guide the study, the researchers postulated four null hypotheses. Literature was reviewed base on the variables under study to facilitate the discussion of findings. Survey research design was adopted for the study. This was considered most appropriate because it allows the researchers to make inferences and generalization of the population. The sample for the study was made up of 400 males and females in Obudu town. The selection was done through the simple random sampling technique, this was to give equal and independent opportunity to all members of the population. 
The main instrument used for data collection was the questionnaire designed by the researchers. Chi-square $\left(\mathrm{x}^{2}\right)$ and Pearson product moment correlation statistical analyses was employed to test the hypotheses, directing the study to ascertain whether to reject or retain them. The hypotheses were subjected to testing at 0.05 level of confidence.

The result of the analysis indicated that significant relationship exist between population growth and pressure on social services, housing and loss of agricultural land at the urban periphery in Obudu town. The significant relationship also exists between population growth and environmental pollution in Obudu urban.

\subsection{Conclusion}

From the findings made the following conclusions were reached.

- There is a significant relationship between population growth and housing pressure in Obudu town.

- There is a significant effect of population growth and pressure on social services in Obudu town.

- There is a significant relationship between population increase and loss of agricultural land at the urban periphery.

- There is a significant relationship between population growth and environmental pollution in Obudu town.

\subsection{Recommendations}

Based on the findings and conclusion the following recommendations were made:

- More social services should be provided by the government to the people of Obudu town.

- Family planning programme which will help to educate the people should be introducedto guide against population explosion.

- Late marriage should be encouraged and the minimum age at which people could marry should be fixed by law.

- More houses should be provided by the government to its citizens.

- The government should adopt migrant policies which will help to control population growth.

- There should be development control to guide against illegal development.

- Care must be taken to ensure that agricultural lands at the periphery are protected from unnecessary sprawl.

- There should be provision of infrastructure at the rural areas to ensure that rural urban migration to Obudu does not add to the problems already experienced since some of these migrants come from the rural areas to swell the Obudu urban population.

- Environmentally friendly policies that hinges on sanitation be inculcated by government to guide against pollution.

- Government should as a matter of urgency pass legislation against unnecessary dumping of refuse. Victims of this act should be brought to book.

\section{References}

i. Adeleke, B.O \& Leong, G.C. (1981). Certificate physical and human geography. Ibadan: Ibadan University Press.

ii. Anyanwuocha, R.A, (2004). Fundamental of economics for students. Uyo: First African Publishers Limited.

iii. Elom, O. (2007). Who is who in Cross River State Councils. Calabar: Calabar Government Press.

iv. FGN (1999). National Population Census Abuja, Government Press.

v. Hoyt, H. (1939). Recent distortions of the classic models of urban structures as in the annals of the America academy of political and social science.

vi. Hull. R. (2001). Practical issues in human settlement and health.

vii. Isangedighi, A.J. et al (2004). Fundamental of research and statistical in education and social sciences. Calabar: Unical Publisher Lt.

viii. Mabogunje, A. (1999). The development process. A spatial perspective, $2^{\text {nd }}$ edition London: Unwin and Hyman.

ix. Mericle, J.B. (2007). The changing nature of cities and challenges of planning practiced a global perspective.

x. National Population Commission (NPC: 1991 - 2006 census) Calabar Branch.

xi. Ndukwe, C. (2005). Issues in rural and community development. Enugu: John-Jacobs Classic Publishers Ltd.

xii. Sule, R.O. (2004). The environmental consequence or rapid urbanization in countries of development world. Calabar: Calabar Thumbprints International Company.

xiii. Sule, R.O. (2006). Paradigms of urbanization and urban planning in Africa. Calabar: Calabar Thumbprints International Company.

xiv. Sule, R.O. (2008). Sustainable urban physical development planning in Nigeria. Calabar: Calabar Thumbprints International Company.

xv. Umoh, B.D. (2012). Population studies. Enugu: MNN Press.

\section{Appendix}

This research work is on the impact of population growth on urban expansion in Obudu town of Cross River State of Nigeria. You are required to respond to the under-listed items consciously. Your information will be treated with absolute confidentiality.

Thanks in anticipation of your kind consideration.

Instructions: Tick $(\sqrt{ })$ as appropriate

Section A: Personal data 
Sex: (a) Male

(b) Female

Age: (a) $15-19$ (b) $20-29$ (c) $30-39$

(d) 40 and above

Marital status: (a) single (b) married

Location (LGA):

Section B

Now answer the following below:

1. Housing classification (a) good (b) fair (c) better (d) excellent

2. Housing ownership (a) owner (b) tenant (c) lease (d) hire

3. $\quad$ Housing structural type (a) occupied (b) temporal (c) permanent (d) unoccupied

4. $\quad$ Number of rooms in the building (a) one (b) 3 (c) 4 (d) more

5. $\quad$ Toilet facilities (a) pit toilet (b) watercloset (c) squat and throw (d) stream defection

6. $\quad$ Bathing facilities (a) bucket system (b) shower system (c) stream bath (d) bath tub

7. Method of waste disposal (a) burying (b) burning (c) indiscriminate (d) dump stand

8. What are the environmental problems associated with population growth (a) air pollution (b) water pollution (c) noise pollution $(\mathrm{d})$ land pollution

9. What are the social problems associated with population growth and urban expansion in your area

$\begin{array}{lll}\text { (a) Shortage of housing stock } & \text { (b) high crime rate (c) rent increase (d) all of the above. }\end{array}$

10. Do you experience any form of social services shortage?

(a) Yes (b) No. (c) not definite (d) all of the above

11. If your answer to question 10 is Yes, what are those social services

$\begin{array}{ll}\text { (a) inadequate health care services (b) inadequate electricity } & \text { (c) poor road network (d) poor water supply }\end{array}$

12. What are the housing problems associated with population growth

(a) increase in rate (b) shortage of housing stock (c) poor housing quality (d) regular building collapse

13. What are the problems post to agricultural land by urban expansion

(a) lost of fertile farm land for farming (b) fragmentation of the ecosystem (c) destruction of biotic and abiotic factor (d) all of the above

14. How would you want government to address the problems of population growth and urban expansion in Obudu (a) provide more social service (b) build low cost housing unit (c) reduce renting cost of housing units (d) create job opportunities 